International Journal of Instruction e-ISSN: 1308-1470 • www.e-iji.net
October $2017 \bullet$ Vol.10, No.4

p-ISSN: 1694-609X

pp. $87-108$

Received: 01/04/2017

Revision: 12/06/2017

Accepted: 16/06/2017

\title{
Debate Instruction in EFL Classroom: Impacts on the Critical Thinking and Speaking Skill
}

\author{
Jaya Nur Iman \\ University of Indo Global Mandiri, Indonesia, jaya.nur.iman95@gmail.com
}

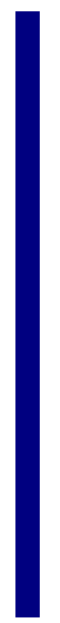

\begin{abstract}
The research was aimed to find out whether or not using debate significantly improved the students' critical thinking and speaking skill achievements and how much debate contributed to each aspect of critical thinking and speaking skill. A quasi-experimental study of non-equivalent pretest- posttest control group design was used in this research. The findings showed that (1) there was a significant improvement in critical thinking and speaking skill, (2) there was also a significant mean difference between the experimental and control groups, (3) there was high contribution of the debate toward the whole aspects of critical thinking $(0.821$ or $82.1 \%)$. Partially, the contribution of each aspect of Critical Thinking (CT) toward critical thinking (total) achievement was as follows: context was $32.3 \%$, issue was $26.2 \%$, implication was $20.1 \%$, and assumption was $6.6 \%$. On the other side, there was high contribution of the debate toward the whole aspects of Speaking Skill (0.961 or $96.1 \%)$. Partially, the contribution of each aspect of Speaking Skill (SS) toward Speaking Skill (total) achievement was as follows: fluency was $67.4 \%$, grammar was $13.7 \%$, pronunciation was $8.3 \%$, comprehension was $5.4 \%$, and vocabulary was $1.4 \%$.
\end{abstract}

Keywords: debate, critical thinking, speaking skill, instruction, EFL classroom

\section{INTRODUCTION}

English is considered as a dominant and acceptable tool for global communication. The language is utilized to various degrees by people from all over the world. On a small scale, people who speak different mother tongues verbalize English for different aims, for instance, to have an access to advanced academic publications, to study abroad, and to make their career opportunities better. On a larger scale, English is regarded as an important language in various fields, including international trade, science and technology, banking, manufacturing, diplomacy, entertainment, education, and so forth. The use of English as an international language plays a significant role in the globalization era. At the current time, we are required to be able to communicate in English. This means English becomes a means of communication among people in the world and plays a vital and a special role in the globalization era, particularly in the educational system in Indonesia. For that reason, it is very prominent for us to learn 
English both the language itself (Linguistic Competence) and how to practice oral and written communication (Linguistic Performance).

Nowadays, English is an important language in Indonesia. It can be seen that English becomes the first foreign language that is taught in Indonesia starting from elementary school up to university level and also the involvement of English as one of the essential subjects in the curriculum in Indonesian education. It seems the development of English language teaching in Indonesia touches the recent English curriculum objectives. The objective of teaching and learning English at schools is to bring along the student to a better understanding and ability of the language. English is one of the tested subjects from the three important subjects required in national examination at senior high school. At this point, the students, however, are necessarily required to achieve a certain score in order that they can get the passing grade. Not only the grammatical aspect is important, but also the communicative one. This point is revealed in the English curriculum that the students' instructional materials must be on the basis of the communicative skill acceptable for the students' daily needs. This is in line with Depdiknas RI [Departemen Pendidikan Nasional Republik Indonesia] (2006) which states that the general standard objectives of English language teaching at Senior High Schools in Indonesia are determined as follows: (1) Developing communicative competence both in oral and in writing in order to pursue the level of informational literacy; (2) Raising awareness of the nature of English as a foreign language in order to compete with other countries in the global community; and (3) Developing students' comprehension about the relation between language and culture.

In addition, the focus of English language teaching in Senior High School based on English school-based curriculum is as follows; firstly, discourse ability is students' competence to understand and produce oral and written texts in relation to four language skills (listening, speaking, reading, and writing), secondly, students' competence to comprehend and produce various short functional and monolog texts, and essay texts such as procedure, descriptive, recount, narrative, report, news item, analytical exposition, hortatory exposition, spoof, explanation, discussion, review, and public speaking, thirdly, other competences are linguistic competence (grammar, vocabulary, spelling, and written rules), social cultural competence (language expression based on the community context), strategic competence (problem solving in communication occurred), and discourse maker competence (Depdiknas RI, 2006). Hence, it can be inferred that it is very necessary to teach English in senior high school particularly to improve the students' fluency and accuracy of English communicative competence in relation to the recent English curriculum objectives in which the teaching of speaking skill then has become increasingly vital in the English as a foreign language context.

The teaching of speaking skill has become increasingly important in English as a second or foreign language (ESL/EFL) context. The teaching of speaking skill is also important due to the large number of students who want to study English in order to be able to use English for communicative purposes. In line with that, Brown (2004, p. 140) defines "speaking as a productive skill that can be directly and empirically observed; those observations are invariably colored by the accuracy and effectiveness of a test-taker's 
listening skill, which necessarily compromises the reliability and validity of an oral production test." In addition, speaking is also a multi-sensory activity because it involves paralinguistic features such as eye-contact, facial expressions, body language, tempo, pauses, voice quality changes, and pitch variation which affect conversational flow (Thornbury \& Slade, 2005, p. 9). Similarly, Richard (1990) asserts that the mastery of speaking skills in English is a priority for many second and foreign language learners. Learners consequently often evaluate their success in language learning as well as the effectiveness of their course on the basis of how well they feel they have improved in their spoken English proficiency. In short, speaking is a process of interaction between speaker and listener in which they share and receive the information that involves paralinguistic features and the speaking skill mastery also becomes necessary for the language learners to interact with others in the conversation.

Ironically, according to Marcelino' study (2005), he mentioned that most of the students as EFL learners are passive. A lot of them are shy to use English in real communication. Many of them pay attention to forms and rules when they communicate with others. Most of them do not practice English in real communication and situations. Only few practice English in the classroom. Most of the learners fail in acquiring English because of lack of motivation (p. 33). Similarly, Huda (1997) asserts that although oral communication ability is an important skill required by English learners, it is a difficult skill to develop, because English is not spoken in the community in Indonesia. Besides, the students are not accordingly and actively exposed in English classes. Based on Huda' research involving 6056 respondents from eight provinces, it was found that the majority $(75.5 \%)$ stated that their teachers used a combination of English and Indonesia languages, only $48 \%$ used English and $19.6 \%$ used Indonesia. In addition, the problem found in terms of English achievement in MAN 3 Palembang was still low, it could be seen when the students were asked some questions in English, they could not express their ideas and tended to keep silent as well as to give response in Indonesian. Furthermore, only $54.07 \%$ of the tenth grade students could reach the KKM score (Minimum Achievement Criteria Score). Hence, it can be implied that on one hand, most of the students in Indonesia still come across with some problems in speaking English particularly on their personality and motivation, on the other hand, it happens due to the fast that English is not spoken in Indonesian community and the students also are not fully and actively exposed in English in the classroom.

To learn speaking English, various ways have been used as the method of teaching and learning English to make the students understand easily the English subject starting from the traditional way by using traditional tools (book, chalks, blackboard or whiteboard) into the newer and modern method by using the modern tools such as realia, real object, pictures, music, etc. One of the modern methods that can be used in teaching speaking skill is debate method. It is seen as an active learning process because students will learn more through a process of constructing and creating, working in a group and also sharing the knowledge. In general, debate is one of the speaking classroom activities which requires two teams consisting of two or more speakers speak out their arguments and oppose the opponent's arguments in terms of the topic or motion given. It is supported by Dobson (1987) who asserts that there are some instructional techniques in 
improving students' speaking skill, such as: dialogues, small-group discussion, debate, song, and games. Additionally, Hasibuan \& Batubara (2012) also reveal that debate is a method of language learning which is applied to improve speaking ability as well as critical thinking (p.19). Hence, debate is a method of language learning which is applicable not only to improve the students' speaking skill but also critical thinking.

In addition, debate is potential to develop students' critical thinking and speaking skill. This statement is supported by Walker and Warhust (2000) who claim that debates in the classroom have been effective in increasing critical thinking by letting students connect as they learn subject knowledge. In their classes, they found that $82 \%$ of students thought that they understood the subject matter, and $85 \%$ believed that they learned something valuable. Similarly, Fukuda (2003, p. 417-418), in a debate study conducted with Japanese students, found that "before the debates only $30.8 \%$ of the students were not afraid of expressing their opinions when they were not the same as others'. After the debate this figure rose to $56.7 \%$." He went on to say that "the knowledge or skills which came from the practice in the debates led the students to become more accustomed to expressing opinions."

On the quite contrary to the critical thinking reality, Masduqi (2011) asserts "In today's higher education in Indonesia, many lecturers complain that Indonesian university students do not use their critical thinking skills sufficiently when they are doing both oral and written assignments". Based on his teaching experience both in English and non-English majors, he found out that the students are reluctant to share their ideas and opinions about what they have already read without analyzing and criticizing the opinions from the articles as well as the writers. This is because they were taught by using a teacher - centred approach and did not develop students' critical thinking optimally (p. 192). As the matter of fact, in Scott's (2008) study with 111 college students enrolled in science, technology and society course, the participants' response to a survey question on whether the debate activity has helped them to develop critical thinking skills, yielded a mean score of 3.16 on a scale of 1 (strongly disagree) to 4 (strongly agree) (p.42). It can be then inferred that the university students particularly English major still have barrier to use their critical thinking in instructional activities. Thus, if the university students with English major who are actively exposed in English in the classroom encounter hindrance to use their critical thinking skills, it then can be assumed that the high school students also have a problem in using their critical thinking in the classroom. Yet, debate is one of the instructional activities that can potentially maximize and develop students' critical thinking skills.

In relation to the background above, the writer is interested to conduct the study which is pertaining to debate especially the use of World School Debate Championship (WSDC) to cultivate critical thinking and improve speaking skill of the tenth grade students of MAN 3 Palembang.

\section{Research Problem}

Dealing with the above-mentioned rationale above, the researcher formulated the research questions as follows:

1. Did using debate give a significant improvement on the students' critical thinking and speaking skill? 
2. Did using debate give a significant difference on the students' critical thinking and speaking skill?

3. How much did the aspects of the critical thinking and speaking skill contribute to the students' critical thinking and speaking achievements?

Research Objectives

Based on the research problem above, the researcher attempted to:

1. Find out whether or not using debate gives a significant improvement on the students' critical thinking and speaking skill.

2. Find out whether or not using debate gives a significant difference on the students' critical thinking and speaking skill.

3. Find out how much the aspects of the critical thinking and speaking skill contributed to the students' critical thinking and speaking achievements.

\section{LITERATURE REVIEW}

\section{Critical Thinking}

The concept of critical thinking has been refined and enriched since its appearance 2500 years ago. By looking through literature, various definitions were found to help one understand the nature of critical thinking. Dewey (1993) is the first to define critical thinking as "reflective thinking... active, persistent, and careful consideration of a belief or supposed form of knowledge in light of the grounds which support it and the further conclusions to which it tends" (p. 99-116). John Dewey (1993) further suggested a 5phase critical thinking model which included (1) suggestions, (2) problem definition, (3) hypothesis generation, (4) reasoning and (5) hypothesis testing. In this definition, Dewey further states that the necessity for individuals to actively and persistently participate in their own thinking process through reflections, giving reasons and interpretations to the conclusions and evaluate it. Learning improves in the process of reflective thinking. In accordance with the above-mentioned critical thinking model, the writer would like to explain and relate it to the debate process and activity. In the phase of suggestions, the students will have many suggestions in relation to the debate motion because when they have brainstorming, there will be information exchanging in it. For that reason, the students in debate team should select the most eligible ideas or information that suit the debate motion.

In the phase of problem definition, the students should define the problem of the debate motion word by word and as a whole in order that the debate process will not be out of track. In the phase of hypothesis generation, the students should yield the ideas or explanation and provide some solutions on the basis of the fact or evidence to support the arguments. In the phase of reasoning, the students should be able to critique and give vivid and strong reason which this must be supported by examples and data and interpret them pertaining to create a logical and relevant argument to the reason and case being proven. In the last phase, the students should make an evaluation of the arguments and present them accordingly. Therefore, in order to be a critical thinker, the students should possess and follow the 5-phase critical thinking model offered by Dewey. In line with that, Bloom (1956) terms critical thinking as the ability to gain knowledge through the exploration of ideas concerning the following six levels: knowledge, comprehension, 
application, analysis, synthesis, and evaluation. Knowledge and comprehension belong to the low level of thinking skills, while the other elements belong to the higher level of thinking skills.

In relation to the six levels of critical thinking model by Bloom, the teacher should recognize what the students should undergo in each level in terms of debate process and activity in order that they can be categorized as a critical thinker. The following things are the things that the writer would like to pay more concern on; in the level of knowledge, the students should learn how to understand the debate motion, research the facts or evidence, and then exchange the information among the members of debate team; in the level of comprehension, the students should learn how to internalize, conceptualize, and connect the information gathered; in the level of application, the students should learn how to utilize and organize the information including facts, sources, and current data properly in order that it can be several good arguments; in the level of analysis, the students learn how to break down the acquired information into several viewpoints and analyze the problem or consequences as well as provide the solution; in the level of synthesis, the students learn how to recognize and compile the information by combining several viewpoints in an effort to prove alternative solution; finally, in the level of evaluation, the students should learn how to present, defend their arguments as well as oppose the opponents' arguments in a proper way, and make a judgments about the arguments presented.

The above-stated critical thinking models are also supported by Rybold (2006) who points out that critical thinking is thinking about how we think. It is the process of asking and answering questions and trying to understand how and why we come to the conclusions that we do. This is an essential skill for debate because debaters need to plan what they will say, anticipate the other team's response, and think of an argument to counter the other team's arguments. Debate is not just a discussion between two sides. Rather, it is a contest in which each side is trying to win by presenting a better argument and making the other team's argument look less reasonable or weak (p. 74).

In addition, he further asserts that many other skills are involved in developing critical thinking. When we learn to argue and defend our own position, we are critical thinkers. When you argue against another's position, you are a critical thinker. When we change your mind because of the arguments you hear, we are critical thinkers. When we understand that argumentation occurs whenever someone communicates to influence others to change their beliefs or behavior, we are critical thinkers (Rybold, 2006, p. 75). Similarly, critical thinking is the art of analyzing and evaluating thinking with a view to improve it. They, then, explain further the result of well-cultivated thinker as follows: A well-cultivated critical thinker: (a) raises vital questions and problems, formulating them clearly and precisely; (b) gathers and assesses the relevant information, using abstract ideas to interpret it effectively; (c) comes to well-reasoned conclusions and solutions, testing them against relevant criteria and standards; (d) thinks open-mindedly within alternative systems of thought, recognizing and assessing, as need be, their assumptions, implications, and practical consequences; and (e) communicates effectively with others in figuring out solutions to complex problems (Paul and Elder, 2008). 
Examining different critical thinking definitions, one thing is agreed upon by most researchers: that is critical thinking includes not only critical thinking skills (containing both a process of thinking and thinking ability), involving analysis, interpretation, inference, explanation, evaluation and self-regulation but also critical thinking dispositions including clarity, accuracy, precision, consistency, relevance, sound evidence, good reasons, depth, breadth, fairness (Scriven and Paul, 1987). Hence, critical thinking is, in short, a process of thinking or an important thinking ability that the students must possess to gain knowledge, such as analysis, interpretation, inference, explanation, and evaluation to encounter and cope with various problems, formulate the questions, and provide possible solutions and plans effectively.

\section{Speaking Skill}

The teaching and practice of speaking skill should exist in language classrooms because this can truly enable the student to communicate in English; thus, speaking skill requires the special treatment. Speaking skill also plays an important role for language learners who use it for instruction, discussion, and arguments presentation. However, the teachers frequently come across with some problems in relation to speaking instructional. This is strengthened by Padmadewi (1998) who found out that students attending a speaking class often felt anxious due to pressure from the speaking tasks which require them to present individually and spontaneously within limited time. Meanwhile, Tutyandari (2005) mentioned that students keep silent because they lack self-confidence, lack prior knowledge about topics, and because of poor teacherlearner relationship. In order to cope with students' limited knowledge, she advised speaking teachers activate the students' prior knowledge by asking questions related to topics under discussion. She also mentioned that students' self-confidence can be enhanced and their anxiety can be reduced by giving them tasks in small groups.

On the basis of the above-revealed statement, the students are still having problems in English speaking classroom. The teacher should then be able to figure out the instructional activity that can stimulate students to speak or interact with others. One of the applicable methods to improve the students' English-speaking skill is debate. This statement is supported by Dobson (1987) who asserts that debate helps students speak more fluently and during a debate they can represent their feelings and thoughts on an issue. Having the same thought, Maryadi (2008) states "debate can motivate students' thinking, moreover if they must defend their stand or opinion which is in contradiction with conviction themselves". This strategy can involve all students to be active, not only debate performer. In addition to providing meaningful listening, speaking and writing practice, debate is also highly effective for developing argumentation skills for persuasive speech and writing. For that reason, it can be concluded that debate is one of the best speaking instructional activity that can trigger the students to speak and express their feelings, and thoughts.

Additionally, speaking is social, in the sense that it establishes rapport and mutual agreement, maintains and modifies social identity, and involves interpersonal skills (Thornbury and Slade, 2005, p. 17). This social element is expressed through wishes, feelings, attitudes, opinions and judgments, which can clash with the formal nature of the classroom when teaching speaking. Moreover, according to Gert and Hans (2008), 
speaking is speech or utterances with the purpose of having intention to be recognized by speaker and the receiver processes the statements in order to recognize their intentions (p. 207). Chaney (1998) also reveals that speaking is "the process of building and sharing meaning through the use of verbal and non-verbal symbols, in a variety of contexts" (p. 13). Therefore, speaking, in brief, is the ability or a skill to send and receive the message during daily life communication in which the speaker also requires to build and share meaning as well as express the ideas using verbal and non-verbal symbols fluently.

Furthermore, the success in communication is often dependent as much on the listener as on the speaker. There are three components to make fluent in producing speech, namely vocabulary, pronunciation, and grammar. Harris (1974) states that speaking is a complex skill requiring the simultaneous use of a number of different abilities which often develop at different rates (p. 81). He adds that there are five components of speaking ability. They are: pronunciation, including the segmental features vowels and consonants and the stress and intonation patterns; grammar; vocabulary; fluency, the ease and speed of the flow of speech; comprehension; requires a subject to respond to speech as well as to initiate it. In line with that, Lado (1995) also says that either four or five components are generally recognized in analysis of speech process. They are: a) Pronunciation (Including the segmental features-vowels and consonant and the stress and intonation/ pattern), b) Grammar, c) Vocabulary, d) Fluency (the case and the speech of the flow of speech), and e) Comprehension. From the revealed-above definitions and explanation, the writer can imply that speaking is a prominent skill which has many functions in daily conversation. When the speaker has a conversation with the listener, the speaker can express their ideas, feelings, and thoughts either through verbal or non-verbal symbols to the listener.

Debate

Debate is definitely one of the most exciting and valuable experiences for the high school or college students. Those who learn to debate well learn how to research and gather a significant question in depth. They also learn how to organize research or arguments into a meaningful and persuasive presentation. In addition, the debater learns to defend his or her presentation against the attack of the opponents through critical thinking and listening. Thus, the good debater should know how to search and research the data, build the constructive arguments, present and defend the arguments, refute and rebut the opponents' arguments, and so forth.

Debate is the process of presenting ideas or opinions which two opposing parties try to defend their idea or opinion. Krieger (2005) says that debate is an excellent activity for language learning because it engages students in a variety of cognitive and linguistic ways. Similarly, Halvorsen (2005) says that debate forces students to think about the multiple sides of an issue and it also forces them to interact not just with the details of a given topic, but also with one another. In addition to critical thinking skills, debates also demand the development of oral communication skills, which are vital for success in most careers (Combs \& Bourne, 1994). "Debate involves not only determining what to say but how to say it" (Roy \& Macchiette, 2005, p. 265). Williams, McGee, and Worth (2001) surveyed 286 participants of competitive debate teams at 70 different 
universities. These students rated improved communication skills as the most substantial benefit of debate participation. Similarly, the marketing students surveyed by Combs and Bourne (1994) reported a statistically significant improvement in their and their peers' oral communication skills as a result of in-class debate participation.

From the above-mentioned explanation, it can be inferred that debate is considered statistically significant in accordance with improving students' critical thinking and speaking skill. This also can stimulate the students to think critically in relation to the multiple viewpoints in the debate process and activity and require the students to deliver their argument and viewpoints structurally.

\section{World School Debate Championship (WSDC) Rules}

In addition, there are actually many debate systems in the world such as; British Parliamentary Debate, Australasian Parliamentary Debate, World School Debating Championship, and so forth. In this research, the writer was primarily concerned on World School Debating Championship which was described as follows:

The Indonesian Schools Debating Championships uses the World Schools format. This format work as follows (Wirawan, 2010):

1. There are 2 teams debating, each consists of 3 (three) debaters who would be $1^{\text {st }}, 2^{\text {nd }}$ and $3^{\text {rd }}$ speakers of the team.

2. One team shall be the Government/Affirmative side - the side agreeing with the motion, the other team shall be the Opposition/Negative side - the side disagreeing with the motion.

3. Each speaker will deliver a substantial speech of 8 (eight) minutes in duration, with the affirmative going first. Afterwards, either the $1^{\text {st }}$ or $2^{\text {nd }}$ speaker on both sides will deliver the reply speeches of 4 (four) minutes in duration, with the negative going first. 4. Thus, the complete order of speaking during a debate is as follows:

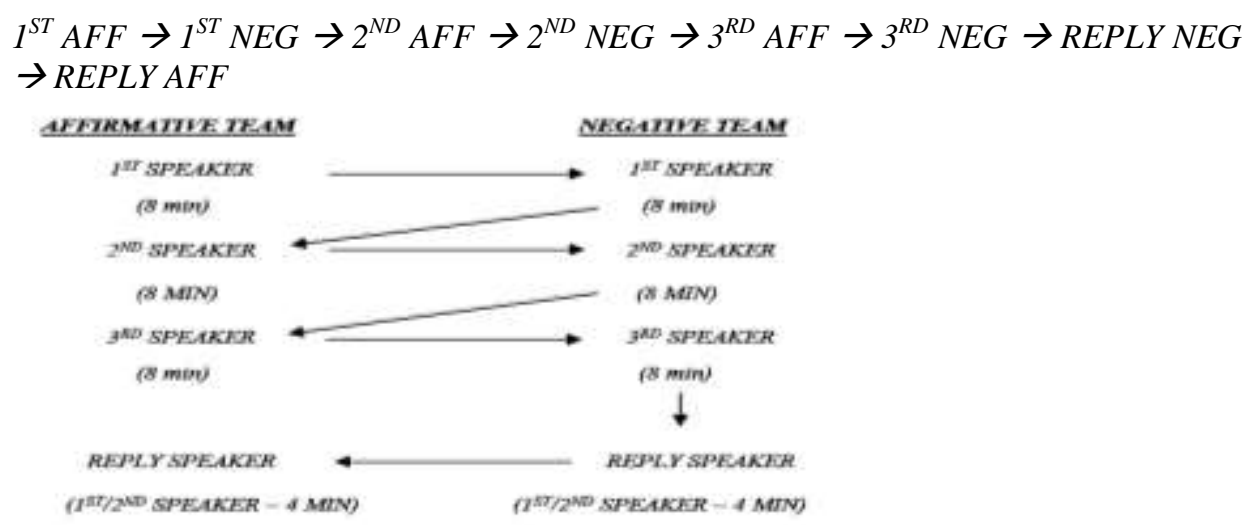

5. In a substantive speech, members of the opposing team are allowed to give an interruption, called points of information (POI), to the speaker delivering the speech. POIs may be delivered between the $1^{\text {st }}$ and $7^{\text {th }}$ minute of the 8 -minute-speech. No POIs are allowed in a reply speech. The speaker has full authority to accept or reject a POI. 


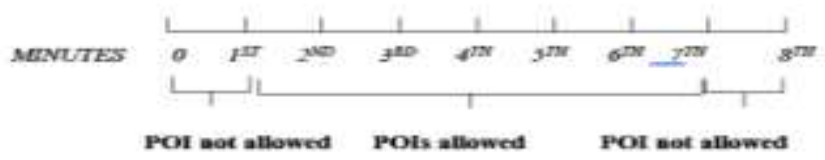

6. A time keeper shall signal the time. There will be one knock at the end of the $1^{\text {st }}$ and $7^{\text {th }}$ minutes, to signal the starting and ending times for point. And two knocks at the $8^{\text {th }}$ minute to signal that delivery time for the speech has ended. Any debater speaking before 7 minutes shall be considered under-time and his/her points could be reduced. Any debater speaking after 8 minutes 30 seconds shall be considered overtime and his/her points could be reduced as well.

7. For reply speeches, there will be one knock at the $3^{\text {rd }}$ minute, to signal that delivery time is almost over, and two knocks at the $4^{\text {th }}$ minute.

8. Every debate shall be judged by an odd number of judges and only the judges shall decide who wins the debate (there is no draw in the result of a debate).

9. In Indonesian, every team is given 30 minutes preparation time after the motion is released and before the debate begins. During this preparation time, teams are not allowed to get help from anybody (be it coaches, teachers, parents or friends) or use laptops, PDAs, or any other communication devices.

\section{METHOD}

In this research, the quasi-experimental design was used and it was chiefly focused on the nonequivalent groups pretest-posttest control group design. Two groups were required in this method that are actually experimental and control groups. In the experimental group, the researcher gave a pre-test, treatment by using World Schools Debating Championship and then post-test. Meanwhile in the control group, the researcher only gave a pre-test and post-test without any treatment. The following is the research design used:

\begin{tabular}{|c|c|c|c|}
\hline \multicolumn{4}{|c|}{ Nonequivalent Groups Pretest Posttest Control Group Design } \\
\hline Group & $\underline{\text { Pretest }}$ & Intervention & Posttest \\
\hline $\mathrm{A}$ & $\mathrm{O} 1$ & $\bar{X}$ & $\overline{\mathrm{O} 2}$ \\
\hline B & $\mathrm{O} 3$ & - & $\mathrm{O} 4$ \\
\hline \multicolumn{4}{|c|}{ Time } \\
\hline
\end{tabular}

Source: (McMillan and Schumacher, 2010, p.278)

Where,

$\begin{array}{ll}\text { A } & \text { : Experimental Group } \\ \text { B } & \text { : Control Group } \\ \text { O1 } & \text { : Pretest of experimental group } \\ \text { O2 } & \text { : Posttest of experimental group } \\ \text { O3 } & \text { : Pretest of control group } \\ \text { O4 } & \text { : Posttest of control group } \\ \text { X } & \text { : Treatment in the experimental group } \\ - & \text { : No treatment }\end{array}$




\section{Population and Sample}

The research was conducted at the Islamic Senior high schools MAN 3 Palembang. The population of the research was the tenth grade students of the of Islamic Senior high schools MAN 3 Palembang in the academic year of 2013-2014. Forty-eight students were selected purposively as the research sample in which each group consisted of 24 students, respectively. The students involved in this research were all in the same academic year and taught by the same English teacher and were not having English course during the research was carried out.

\section{Instrumentations}

In collecting the data, the test was used to measure the students' critical thinking and speaking skill. Pertaining to the test given, the students were asked to choose one of the speaking topics provided in the form of monologue. To assess the students' speaking achievement, the researcher used SOLOM (Student Oral Language Observation Matrix) which comprising of the aspects of speaking ability such as, comprehension, vocabulary, pronunciation grammar, and fluency. The SOLOM is a rating scale that teachers can use to assess their students' command of oral language on the basis of what they observe on a continual basis in a variety of situations. The teacher matches a student's language performance in comprehension, vocabulary, fluency, grammar, and pronunciation to descriptions on a five-point scale for each. Pertaining to assessing the critical thinking achievement, the researcher used critical thinking rubric which comprising of the aspects of critical thinking such as: identifying and explaining issues, recognizing stakeholders and contexts, evaluating assumptions, evaluating evidence, and evaluating implications, conclusions, and consequences. Since both classes were given a pre-test and a post-test, each group was given the test with the same speaking topics to assess the critical thinking and speaking skill.

In order to figure out the reliability of the test, the researcher used inter-rater reliability. The inter-rater reliability would be checked by using raters' judgements on the language produced by students in terms of oral test of English. After giving test, the students' scores were produced by two raters independently and a correlation coefficient was calculated between them for each; speaking skill (SS) and critical thinking (CT). From the calculation, as it could be seen in table 1 , the results showed that there were significant correlations between two raters' judgments for both speaking and critical thinking, it could be concluded that two raters' judgments for speaking and critical thinking were reliable. The results of inter-rater reliability could be seen in the table below.

Table 1

Inter-rater Reliability of Pretest and Posttest

\begin{tabular}{ccccccccc}
\hline Variables & \multicolumn{7}{c}{ Pearson Product Moment Correlation } \\
\cline { 2 - 9 } & \multicolumn{7}{c}{ Experimental Group } & \multicolumn{5}{c}{ Control Group } \\
& Pretest & Sig. & Posttest & Sig. & Pretest & Sig. & Posttest & Sig. \\
\hline SS & .617 & .001 & .701 & .000 & .499 & .013 & .709 & .000 \\
\hline CT & .500 & .013 & .649 & .001 & .665 & .000 & .693 & .000 \\
\hline
\end{tabular}




\section{Instructional Procedures}

The task of debate was applied in the experimental group as the English teaching activity. The instructional procedures were explained as follows: (a) the teacher explains the World School Debate Championship technique (the objective of debate, components of debate, outline of debate, the rules of debate, and how to debate), (b) the teacher presents the motion or debate topic, (c) the teacher divides the class in debate groups/team: Proposition and Opposition team, (d) the teacher selects debaters/speakers: 3 for Proposition and 3 for Opposition, (e) the teacher selects the chairperson and time keeper. Ideally, for the first debate activity, the teacher should be acting out as a chairperson, (f) On the day of debate, the teacher arranges the position of chairperson, debaters, and time keeper before starting the debate, $(\mathrm{g})$ Doing the debate: opening the debate activity (chairperson), each speaker presents speech and rebuttal argument (debating), the first speaker of the proposition team, the first speaker of the opposition team, the second speaker of the proposition team, the second speaker of the opposition team, the third speaker of the proposition team, the third speaker of the opposition team, reply speech by $1^{\text {st }}$ or $2^{\text {nd }}$ speaker of opposition team, and reply speech by $1^{\text {st }}$ or $2^{\text {nd }}$ speaker of proposition team, (h) debate closing by chairperson (i) the teacher asks the student to explain the summary of debate, (j) teacher and students conclude the learning materials, (k) the teacher adds the summary from their debate, (l) the teacher informs the debate motion for the next debate meeting, and $(\mathrm{m})$ teacher dismisses the class. This experiment was done for one session of lesson and occurred in 21 teaching sessions in which each session lasted for 90 minutes excluding the pretest and posttest.

\section{Data Analysis}

The data analysis was taken from the tests. To interpret the students' score individually, the range of critical thinking was as follows: excellent (19-24), good (13-18), average (7-12), and poor $(<7)$. Meanwhile, the range of speaking skill was as follows: excellent $(21-25)$, good $(16-20)$, average $(11-15)$, poor $(6-10)$, and very poor $(<6)$. In analyzing the data of students' critical thinking and speaking skill, rubrics were used in this research. Paired sample t-test was used to see whether there was improvement between the students' pretest and posttest for each group. Independent sample t-test was used to see the significant difference between the students' posttest of the two groups. And the Stepwise regression analysis was used to see the contribution of each aspect of critical thinking and speaking skill to both students' critical thinking and speaking skill achievements.

\section{FINDINGS}

\section{Descriptive Statistics}

This section discussed the descriptive statistics, the progress analysis (Paired sample ttest), the mean difference analysis (Independent sample t-test), and the percentage analysis of each aspect contribution (Stepwise regression analysis).

In Table 2, the results showed there was a significant difference in students' Critical Thinking (CT) and Speaking Skill (SS) achievement in the experimental and control 
group. In the experimental group, the CT results showed that $100 \%$ students were in good category with the mean score 16.16. Based on the category of score range, it could be concluded that the students' critical thinking achievement of the experimental group was in good category. For the speaking skill, the result showed that $100 \%$ students were in good category with the mean score 17.93. Based on the category of score range, it could be concluded that the students' speaking skill achievement of the experimental group was in good category.

On the other hand, in the control group, the CT results showed that $29.2 \%$ students were in average category with the mean score 11.57 and also $70.8 \%$ students were in good category with the mean score 14.85 . Therefore, it could be concluded that the students' critical thinking achievement of the control group was in good category. For SS results, $66.7 \%$ students were in average category with the mean score 13.34 and $33.3 \%$ were in good category with the mean score 16.50 . From the results, it could be concluded that the students' speaking skill achievement of the control group was in average category.

In Table 2, for the critical thinking achievement, the mean scores of the students were in the average (11.57) and good categories (15.62) respectively. Meanwhile, for the speaking skill achievement, the mean scores of students were in the average (13.34) and good categories (17.57) respectively. Moreover, the mean scores of students' critical thinking and speaking skill achievement in both groups were 13.59 and 15.45 . It can be concluded that the mean score of the students' critical thinking was in good category and students' speaking skill achievement was in good category.

In terms of frequency and percentage of students' critical thinking in both groups, there were 7 students $(14.6 \%)$ who were in the average category, and 41 students $(85.4 \%)$ in very good category. The result showed that most of the students' critical thinking was in good category (85.4\%). On the other hand, the results of the speaking skill achievement showed that there were 16 students $(33.35 \%)$ in average category and 32 students $(66.65 \%)$ in good category. The result showed that most of the students' speaking skill was in average category $(66.65 \%)$.

Table 2

The Results of CT and SS in Experimental and Control Groups.

\begin{tabular}{|c|c|c|c|c|c|c|c|}
\hline \multirow[b]{2}{*}{ Variable } & \multirow[b]{2}{*}{$\begin{array}{c}\text { Achievement } \\
\text { Level }\end{array}$} & \multicolumn{3}{|c|}{ Experimental Group } & \multicolumn{3}{|c|}{ Control Group } \\
\hline & & $\begin{array}{l}\text { Mean } \\
\text { score }\end{array}$ & SD & $\begin{array}{c}\text { Frequency and } \\
\text { Percentage } \\
\text { (Each Group) }\end{array}$ & $\begin{array}{l}\text { Mean } \\
\text { Score }\end{array}$ & SD & $\begin{array}{c}\text { Frequency and } \\
\text { Percentage (Each } \\
\text { Group) }\end{array}$ \\
\hline \multirow[t]{5}{*}{ CT } & Poor & - & - & - & - & - & - \\
\hline & Average & - & - & - & 11.57 & .534 & $7(29.2 \%)$ \\
\hline & Good & 16.16 & 1.176 & $24(100 \%)$ & 14.85 & 2.029 & $17(70.8 \%)$ \\
\hline & Excellent & - & - & - & - & - & - \\
\hline & OTAL & 16.16 & 1.176 & $24(100 \%)$ & 13.21 & 2.293 & $24(100 \%)$ \\
\hline
\end{tabular}




\begin{tabular}{|c|c|c|c|c|c|c|c|}
\hline \multirow[b]{2}{*}{ Variable } & \multirow[b]{2}{*}{$\begin{array}{c}\text { Achievement } \\
\text { Level }\end{array}$} & \multicolumn{3}{|c|}{ Experimental Group } & \multicolumn{3}{|c|}{ Control Group } \\
\hline & & $\begin{array}{l}\text { Mean } \\
\text { score }\end{array}$ & SD & $\begin{array}{c}\text { Frequency and } \\
\text { Percentage } \\
\text { (Each Group) }\end{array}$ & $\begin{array}{l}\text { Mean } \\
\text { Score }\end{array}$ & SD & $\begin{array}{c}\text { Frequency and } \\
\text { Percentage (Each } \\
\text { Group) }\end{array}$ \\
\hline \multirow[t]{6}{*}{ SS } & Very Poor & - & - & - & - & - & - \\
\hline & Poor & - & - & - & - & - & - \\
\hline & Average & - & - & - & 13.34 & .831 & $16(66.7 \%)$ \\
\hline & Good & 17.93 & 1.304 & $24(100 \%)$ & 16.50 & .963 & $8(33.3 \%)$ \\
\hline & Excellent & - & - & - & - & - & - \\
\hline & TOTAL & 17.93 & 1.304 & $24(100 \%)$ & 14.39 & 1.744 & $24(100 \%)$ \\
\hline Variable & $\begin{array}{l}\text { Achievement } \\
\text { Level }\end{array}$ & \multicolumn{2}{|c|}{ Mean Score } & \multicolumn{3}{|c|}{$\begin{array}{c}\text { Frequency and Percentage } \\
\text { (Both Groups) }\end{array}$} & $\begin{array}{c}\text { Standard } \\
\text { Deviation }\end{array}$ \\
\hline \multirow[t]{4}{*}{$\mathrm{CT}$} & Poor & \multicolumn{2}{|c|}{-} & \multicolumn{3}{|c|}{-} & - \\
\hline & Average & \multicolumn{2}{|c|}{11.57} & \multicolumn{3}{|c|}{$7(14.6 \%)$} & 0.534 \\
\hline & Good & \multicolumn{2}{|c|}{15.62} & \multicolumn{3}{|c|}{$41(85.4 \%)$} & 1.694 \\
\hline & Excellent & \multicolumn{2}{|c|}{-} & \multicolumn{3}{|c|}{-} & - \\
\hline \multicolumn{2}{|c|}{ TOTAL } & \multicolumn{2}{|c|}{27.19} & \multicolumn{3}{|c|}{$48(100 \%)$} & 2.228 \\
\hline \multicolumn{2}{|c|}{ MEAN SCORE } & \multicolumn{2}{|c|}{13.595} & \multicolumn{3}{|c|}{-} & 0.820 \\
\hline \multirow[t]{5}{*}{ SS } & Very Poor & \multicolumn{2}{|c|}{-} & \multicolumn{3}{|c|}{-} & - \\
\hline & Poor & \multicolumn{2}{|c|}{-} & \multicolumn{3}{|c|}{-} & - \\
\hline & Average & \multicolumn{2}{|c|}{13.34} & \multicolumn{3}{|c|}{$16(33.35 \%)$} & 0.831 \\
\hline & Good & \multicolumn{2}{|c|}{17.57} & \multicolumn{3}{|c|}{$32(66.65 \%)$} & 1.368 \\
\hline & Excellent & \multicolumn{2}{|c|}{-} & & - & & - \\
\hline & OTAL & & & 48 & $00 \%)$ & & 2.199 \\
\hline MEA & N SCORE & & & & - & & 0.379 \\
\hline
\end{tabular}

\section{Statistical Analyses}

\section{The Progressive Analyses (Paired Sample t-test)}

In relation to the result of paired sample T-test in experimental group, the mean score of students' critical thinking achievement in pre-test of experimental group was 10.188 with the standard deviation was 2.1458. Meanwhile, the mean of the students' critical thinking achievement in post-test of experimental group was 16.167 with the standard deviation was 1.1765 . The output data showed that the mean difference of critical thinking achievement between pre-test and post-test in experimental group was 5.9792 with the standard deviation was 1.6647 , and t-obtained was $17.596(\mathrm{p}<0.000)$. On the other note, the mean score of students' written test of critical thinking achievement in pre-test of experimental group was 5.100 with the standard deviation was 1.0142. Additionally, the mean of the students' speaking skill achievement in pre-test of experimental group was 12.229 with the standard deviation was 1.2596. Meanwhile, the mean of the students' speaking skill achievement in post-test of experimental group was 17.938 with the standard deviation was 1.3048 . The output data showed that the mean difference of speaking skill achievement between pre-test and post-test in experimental group was 5.7083 with the standard deviation was 0.9315 , and t-obtained was 30.020 $(\mathrm{p}<0.000)$. Since t-obtained of the critical thinking, written test of critical thinking, and speaking skill were higher than t-table both 1.714 and 2.069. Thus, it could be concluded that null hypotheses $\left(\mathrm{H}_{0} 1\right.$ and $\left.\mathrm{H}_{0} 2\right)$ were rejected and the research hypotheses 
$\left(\mathrm{H}_{\mathrm{a}} 1\right.$ and $\left.\mathrm{H}_{\mathrm{a}} 2\right)$ were accepted which means that there was a significant difference made by experimental group.

In relation to the result of paired sample T-test in control group, the mean score of students' critical thinking achievement in pre-test of control group was 11.875 with the standard deviation was 2.2901. Meanwhile, the mean of the students' critical thinking achievement in post-test of control group was 13.896 with the standard deviation was 2.2936. The output data showed that the mean difference of critical thinking achievement between pre-test and post-test in control group was 2.0208 with the standard deviation was 1.3227 , and t-obtained was $7.485(\mathrm{p}<0.000)$. In addition, mean of the students' speaking skill achievement in pre-test of control group was 12.792 with the standard deviation was 1.4812. Meanwhile, the mean of the students' speaking skill achievement in post-test of control group was 14.396 with the standard deviation was 1.7444. The output data showed that the mean difference of speaking skill achievement between pre-test and post-test in control group was 1.6042 with the standard deviation was 1.4293, and t-obtained was 5.498 ( $\mathrm{p}<0.000)$. Since t-obtained of the critical thinking and speaking skill were higher than t-table both 1.714 and 2.069 , thus, it could be concluded that null hypotheses $\left(\mathrm{H}_{0} 1\right.$ and $\left.\mathrm{H}_{0} 2\right)$ were rejected and the research hypotheses $\left(\mathrm{H}_{\mathrm{a}} 1\right.$ and $\left.\mathrm{H}_{\mathrm{a}} 2\right)$ were accepted which means that there was a significant difference made by control group.

\section{The Difference Analyses (Independent sample t-test)}

From the result of the independent t-test: the mean difference of critical thinking posttest between the experimental and control group was 2.270 and t-obtained 4.316 $(\mathrm{p}<0.000)$. On the other hand, the mean difference speaking skill post-test between the experimental and control group was 3.541 and t-obtained $7.965(\mathrm{p}<0.000)$. Since the $p$ value or output of critical thinking and speaking skill achievement were less than the value of probability 0.05 or 0.025 and t-obtained was higher than t-table (1.678 or 2.012). Hence, the null hypotheses null hypotheses $\left(\mathrm{H}_{0} 3\right)$ were rejected and the research hypotheses $\left(\mathrm{H}_{\mathrm{a}} 3\right)$ were accepted. It means that there was a significant difference in critical thinking and speaking skill achievement between the students who were taught using debate and those who were not.

Table 3

The Results of Progressive and Difference Analyses

\begin{tabular}{|c|c|c|c|c|c|c|c|c|c|c|c|}
\hline \multirow[b]{2}{*}{ Variables } & \multicolumn{2}{|c|}{ Pretest } & \multicolumn{2}{|c|}{ Posttest } & \multirow{2}{*}{$\begin{array}{c}\text { Mean } \\
\text { difference } \\
\text { pre and } \\
\text { posttest } \\
\text { Exp within }\end{array}$} & \multirow{2}{*}{$\begin{array}{c}\text { Mean } \\
\text { difference } \\
\text { pre and } \\
\text { posttest } \\
\text { Cont } \\
\text { within }\end{array}$} & \multirow{2}{*}{$\begin{array}{l}\text { T-value } \\
\text { posttest } \\
\text { between } \\
\text { Exp and } \\
\text { Control }\end{array}$} & \multirow{2}{*}{$\begin{array}{c}\text { T value } \\
\text { of Gain } \\
\text { between } \\
\text { Exp \& } \\
\text { Control }\end{array}$} & \multirow{2}{*}{$\begin{array}{l}\text { The } \\
\text { value } \\
\text { of } \\
\text { Sig.2- } \\
\text { tailed } \\
\text { Exp } \\
\text { within }\end{array}$} & \multirow{2}{*}{$\begin{array}{c}\text { The } \\
\text { value of } \\
\text { iig.2-tailed } \\
\text { Cont } \\
\text { within }\end{array}$} & \multirow{2}{*}{$\begin{array}{c}\text { The value } \\
\text { of Sig.2- } \\
\text { tailed } \\
\text { between } \\
\text { Exp and } \\
\text { Control }\end{array}$} \\
\hline & Mean Exp & $\begin{array}{l}\text { Mean } \\
\text { Cont }\end{array}$ & Mean Exp & $\begin{array}{l}\text { Mean } \\
\text { Cont }\end{array}$ & & & & & & & \\
\hline CT & 10.18 & 11.87 & 16.16 & 13.89 & 5.979 & 2.020 & 2.270 & 4.316 & .000 & .000 & .000 \\
\hline SS & 12.22 & 12.79 & 17.93 & 14.39 & 5.709 & 1.604 & 3.541 & 7.965 & .000 & .000 & .000 \\
\hline
\end{tabular}

Stepwise Regression Analysis

Table 4 and 5 showed the result of multiple regression analysis of critical thinking (CT) and speaking Skill (SS) achievement. The correlation among the Debate and context, issue, implication, and assumption was 0.923 or $92.3 \%$ and the influence of contribution 
of the whole aspects of critical thinking (CT) was 0.821 or $82.1 \%$. Partially, the contribution of each aspect of critical thinking (CT) toward critical thinking (CT) achievement was as follows: context was $32.3 \%$, issue was $26.2 \%$, implication was $20.1 \%$, and assumption was $6.6 \%$. On the other hand, the correlation among the Debate and fluency, grammar, pronunciation, comprehension, vocabulary was 0.980 or $98 \%$ and the influence of contribution of the whole aspects of Speaking Skill (SS) was 0.961 or $96.1 \%$. Partially, the contribution of each aspect of Speaking Skill (SS) toward Speaking Skill (SS) achievement was as follows: fluency was $67.4 \%$, grammar was $13.7 \%$, pronunciation was $8.3 \%$, comprehension was $5.4 \%$, and vocabulary was $1.4 \%$.

Table 4

Summary Statistics of Stepwise Regression Analysis of Each Aspect of Critical Thinking toward Critical Thinking (total)

\begin{tabular}{|c|c|c|c|c|c|c|c|c|c|}
\hline \multirow[t]{2}{*}{ Model } & \multirow[t]{2}{*}{$\mathrm{R}$} & \multirow{2}{*}{$\begin{array}{c}\mathrm{R} \\
\text { Square }\end{array}$} & \multirow{2}{*}{$\begin{array}{l}\text { Adjusted } \\
\text { R Square }\end{array}$} & \multirow{2}{*}{$\begin{array}{l}\text { Std. Error of } \\
\text { the Estimate }\end{array}$} & \multicolumn{5}{|c|}{ Change Statistics } \\
\hline & & & & & $\begin{array}{c}\text { R Square } \\
\text { Change }\end{array}$ & $\begin{array}{c}\mathrm{F} \\
\text { Change }\end{array}$ & df1 & df2 & $\begin{array}{c}\text { Sig. F } \\
\text { Change }\end{array}$ \\
\hline 1 & $.569(\mathrm{a})$ & .323 & .293 & .9895 & .323 & 10.514 & 1 & 22 & .004 \\
\hline 2 & $.765(\mathrm{~b})$ & .586 & .546 & .7926 & .262 & 13.285 & 1 & 21 & .002 \\
\hline 3 & $.887(\mathrm{c})$ & .786 & .754 & .5832 & .201 & 18.795 & 1 & 20 & .000 \\
\hline 4 & $.923(\mathrm{~d})$ & .852 & .821 & .4976 & .066 & 8.466 & 1 & 19 & .009 \\
\hline
\end{tabular}

a. Predictors: (Constant), Context

b. Predictors: (Constant), Context, Issue

c. Predictors: (Constant), Context, Issue, Implication

d. Predictors: (Constant), Context, Issue, Implication, Assumption

Table 5

Summary Statistics of Stepwise Regression Analysis of Each Aspect of Speaking Skill toward Speaking

\begin{tabular}{|c|c|c|c|c|c|c|c|c|c|}
\hline \multirow{2}{*}{$\begin{array}{c}\text { Mod } \\
\text { el }\end{array}$} & \multirow[t]{2}{*}{$\mathrm{R}$} & \multirow{2}{*}{$\begin{array}{c}\mathrm{R} \\
\text { Square }\end{array}$} & \multirow{2}{*}{$\begin{array}{l}\text { Adjusted R } \\
\text { Square }\end{array}$} & \multirow{2}{*}{$\begin{array}{l}\text { Std. Error of } \\
\text { the Estimate }\end{array}$} & \multicolumn{5}{|c|}{ Change Statistics } \\
\hline & & & & & $\begin{array}{l}\text { R Square } \\
\text { Change }\end{array}$ & $\begin{array}{c}\mathrm{F} \\
\text { Change }\end{array}$ & $\begin{array}{c}\mathrm{df} \\
1\end{array}$ & $\begin{array}{l}\mathrm{df} \\
2\end{array}$ & $\begin{array}{c}\text { Sig. F } \\
\text { Change }\end{array}$ \\
\hline 1 & $.821(\mathrm{a})$ & .674 & .659 & .7621 & .674 & 45.423 & 1 & 22 & .000 \\
\hline 2 & $.900(\mathrm{~b})$ & .810 & .792 & .5947 & .137 & 15.124 & 1 & 21 & .001 \\
\hline 3 & $.945(\mathrm{c})$ & .893 & .877 & .4576 & .083 & 15.476 & 1 & 20 & .001 \\
\hline 4 & $.973(\mathrm{~d})$ & .947 & .935 & .3315 & .054 & 19.112 & 1 & 19 & .000 \\
\hline 5 & $.980(\mathrm{e})$ & .961 & .950 & .2916 & .014 & 6.556 & 1 & 18 & .020 \\
\hline
\end{tabular}

a. Predictors: (Constant), Fluency

b. Predictors: (Constant), Fluency, Grammar

c. Predictors: (Constant), Fluency, Grammar, Pronunciation

d. Predictors: (Constant), Fluency, Grammar, Pronunciation, Comprehension

e. Predictors: (Constant), Fluency, Grammar, Pronunciation,

Comprehension, Vocabulary

\section{DISCUSSION}

Pertaining to the results of findings, there were some aspects in the aspects of critical thinking achievement were influenced by debate such as context, issue, implication, and assumption. The correlation between debate and critical thinking was very strong and the aspect that was most influenced by debate was context. This might be caused by the 
process of debate especially pre-debate session and while debate session in which requires the students as the member of debate team to think critically and deliberately in relation to the context recognition to case and arguments pertaining to the debate motion such as they want to bring their case and argument from the context of educational, economic, cultural, political, and so forth. This statement is strengthened by Yin (2009) asserts that the context in debate process is very important because it allows the emergence of alternate or rival explanations. Meanwhile, the contribution of debate toward the issue, implication, and assumption was not as high as that of context, however, the existed value was very small. These might be caused by the students who were not updating and keeping up with the current and factual issue in association with the debate motion. They probably draw the implication, conclusion with no reference and source of the evidence or even experts' thoughts and also they do not know how to evaluate assumption accordingly. This is in line with what is revealed by Tu (2004) that the arguments of debaters should be supported by more thoughtful, more logical data and evidence in debate and they also need more time to think about the issue of the debate topic (p. 56). This is also supported by Nisbett (2003) states that in an ESL/EFL context expert knowledge is required to successfully debate a topic.

Furthermore, the contribution of debate did not emerge in the aspects of perspective and evidence because the value of perspective and evidence aspects did not show up. This might be caused by the students who tended to bring their personal perspective, opinion, and even belief in the process of debate. They also probably delivered their arguments with no evidence in it or their evidence did not really represent the context of the arguments. On the other note, Rybold (2006) claims that in the process of debate, perspectives allow debaters to develop the best arguments for a position without injecting their personal beliefs into the debate. He then explains further that since most debaters are not experts about the topic they are discussing, they must use sources of evidence that provide valid reasons for the audience to believe the position they are asserting. When a debater asserts a point without providing evidence, the other side may state the opposite (known as a counterpoint) without evidence, and both sides will tie on that particular point (p.12). Hence, it could be concluded that the students, the debaters, were not allowed to bring their personal opinion and belief and also the evidence providing was really necessary to support the arguments delivered.

On the other hand, in the aspects of speaking skill all the aspects of speaking skill achievement were influenced by debate such as fluency, grammar, pronunciation, comprehension, and vocabulary. The correlation between debate and speaking skill was very strong and the aspect that was most influenced by debate was fluency. This might be caused by the debate process itself in which the students were delivering and defending their arguments as well as opposing the opponent team's arguments. They also probably tend to be emotional in debate to deliver and argue, they might neglect other speaking skill components like grammar, pronunciation, comprehension, and vocabulary. This is relevant to what Dobson (1987) reveals that debate helps students speak more fluently and during a debate they can represent their feelings and thoughts on an issue. Meanwhile, the contribution of debate toward the grammar, pronunciation, comprehension, and vocabulary was not as high as that of fluency, but the value still 
existed although it was very small. This might be caused by the students' experiences who were not accustomed to using the mechanical language elements (grammar, pronunciation, and vocabulary) in their speech accordingly. On the other hand, the students also did not comprehend what they were debating particularly on the current issue, context, the arguments delivered, and so forth. This in line with what Osime (2010) asserts that knowledge is very important in debate to support our understanding of the debate motion (p. 8). Thus, it stands to the point that there were significant improvements on the students' critical thinking and speaking skill after having a treatment although there were some aspects of critical thinking and speaking skill are not significant, however, it still had a contribution even less toward those aspects.

\section{CONCLUSION}

Based on the results and discussion, three conclusions could be drawn. First, it could be concluded that debate particularly World School Debate Championship (WSDC) significantly improved the students' critical thinking and speaking skill. It was found out that the students in experimental group got higher critical thinking and speaking skill achievement than those in control group after the debate strategy was applied as the treatment. Second, there was a significant mean difference in critical thinking and speaking between the students who were taught using debate and those who were not. Third, there was a significant correlation among total gain score of critical thinking and speaking skill and aspects of each of these variables and also the contribution of debate was high to critical thinking and speaking skill achievement. Hence, it could be concluded that the use of debate significantly improves the students' critical thinking and speaking skill. For the pedagogical impact in ELT, debate instruction is very potential to be implemented in EFL classroom context as in the debate activities the students learn not only about how to speak but also about what to speak. Debate also allows the students to think critically about the issues and to work together with the teammate in terms of searching for the information, fact, data, and so forth as well as to speak out about particular issues academically and accordingly. This is ultimately going to make the EFL learners become well-cultivated and competent speaker.

Therefore, some implications may be highlighted and pondered by English teachers, students, and future researchers. First, the students should be given more exposure in relation to the English-speaking activity for instance the debate application in the classroom particularly World School Debate Championship (WSDC) which can stimulate the students to think critically and increase the students' self-confidence and motivation to speak before public. Second, the school teacher should be able to select appropriate and effective instructional technique and instructional material as well as media to support teaching and learning activities in the classroom. Third, both the school teacher and students should be well-equipped with facilities for instance library which can support them to search for the information needed. In addition, the school must send the teachers to participate in the workshop, seminar, and training in order to upgrade their professional development. Last of all, the future researchers are suggested to carry out the inquiry in relation to other integrated language skills and to use not only tests but also interview and questionnaire to gain in-depth research findings. 


\section{REFERENCES}

Bloom, B. S. (1956). Taxonomy of educational objectives. Handbook I: The cognitive domain. New York, NY: David McKay Company.

Brown, H. D. (2004). Language assessment: Principles and classroom practices. New York: Pearson Education, Inc.

Chaney, A. L. (1998). Teaching oral communication in grades K-8. Boston, MA: Allyn and Bacon.

Combs, H., \& Bourne, S. (1994). The renaissance of educational debate: Results of a five-year study of the use of debate in business education. Journal on Excellence in College Teaching, 5(1), 57-67.

Dewey, J. (1933). How we think: A restatement of the relation of reflective thinking to the educative process. Boston, MA: Health.

Depdiknas RI [Departemen Pendidikan Nasional Republik Indonesia]. (2006). Pedoman Kurikulum Tingkat Satuan Pendidikan untuk Sekolah Menengah Atas Tahun 2006 Jakarta: Depdiknas RI.

Dobson, M. J. (1987). Effective techniques for English conversation groups. Washington, D. C.: United States Information Agency.

Fukuda, S. (2003). Attitudes towards argumentation in college EFL classes in Japan. Proceedings of the First Asia TEFL International Conference (pp. 417-418). Retrieved from http://www.rapidintellect.com/AEQweb/spurn4.html

Gert, R., \& Hans, S. (2008). Handbook of communication competence. Berlin, Germany: University of Bielefeld.

Halvorsen, A. (2005). Incorporating critical thinking skills development into ESL/EFL course. Retrieved from http://iteslj.org/Techniques/Halvorsen-CriticalThinking.html.

Harris, D. P. (1974). Testing English as a second language. New York, NY: McGrawHill Book Company.

Hasibuan, A. L., \& Batubara, I. A. (2012). Implementing problem-based learning in digitalization era through debating practice. Proceedings of the $59^{\text {th }}$ TEFLIN International Conference (pp. 13-30). Surabaya: Widya Mandala Catholic University.

Huda, N. (1997). A national strategy in achieving English communication ability: Globalization perspectives. Jurnal Ilmu Pendidikan, 4(Special Edition), 281-292.

Krieger, D. (2005). Teaching debate to ESL students: A six - class unit. The Internet TESL Journal, 11(2). Retrieved from http://iteslj.org/Techniques/.html.

Lado, R. (1995). Language teaching: A scientific approach. New York, NY: McGrawHill Book Company. 
Marcellino, M. (2005). Competency-based language instruction in speaking classes: Its theory and implementation in Indonesian contexts. Indonesian Journal of English Language Teaching, 1(1), 33-44.

Maryadi, A. (2008). Debate implementation at school. Jakarta: Rineka Cipta.

Masduqi, H. (2011). Critical thinking skills and meaning in English Language Teaching. TEFLIN Journal. 22(2), 185-200.

McMillan, J. H., \& Schumacher, S. (2010). Research in education: Evidence-based inquiry $\left(7^{\text {th }}\right.$ ed). New York: Pearson.

Nisbett, R. E. (2003). Geography of thought: How Asians and Westerners think differently and why. New York: Free Press.

Osime, T. (2010). The debaters: Manual and guidelines. Retrieved from http://www.thedebaters-ng.com/The\%20Debaters\%20Manual\%2001.pdf

Padmadewi, N. N. (1998). Students' anxiety in speaking class and ways of minimizing it. Jurnal Ilmu Pendidikan, 5 [Supplementary Edition], 60-67.

Paul, R., \& Elder, L. (2008). The miniature guide to critical thinking: Concept and tools. Dillon Beach, CA: The Foundation for Critical Thinking.

Richard, J. C. (1990). Conversationally speaking approaches to the teaching of conversation: The language of teaching matrix. New York: Cambridge University Press.

Roy, A., \& Macchiette, B. (2005). Debating the issues: A tool for augmenting critical thinking skills of marketing students. Journal of Marketing Education, 27(3), 264-276.

Rybold, G. (2006). Speaking, listening and understanding: Debate for non-nativeEnglish. New York: International Debate Education Association.

Scott, S. (2008). Perceptions of students' learning critical thinking through debate in a technology classroom: A case study. The Journal of Technology Studies, 10(2), 115-119.

Scriven, M., \& Paul, R. (1987). The critical thinking community. Retrieved from http://www.criticalthinking.org/aboutCT/definingCT.html

Thornbury, S., \& Slade, D. (2005). Conversation: From description to pedagogy. Cambridge: Cambridge University Press.

Tu, C. H. (2004). Online collaborative learning communities: Twenty-one designs to building an online collaborative learning community. Westport, CT: Libraries Unlimited, Greenwood Publishing Group, Inc.

Tutyandari, C. (2005). Breaking the silent of the students in an English language class. Paper presented at the $53^{\text {rd }}$ TEFLIN International Conference, Jogjakarta, Indonesia.

Walker, M., \& Warhurst, C. (2000). In most classes you sit around very quietly at a table and get lectured at ...: Debates, assessment, and student learning. Teaching in Higher Education, 5(1), 33-49. 
Williams, D., McGee, B., \& Worth, D. (2001). University student perceptions of the efficacy of debate participation: An empirical investigation. Argumentation and Advocacy, 37(4), 198-209.

Wirawan, D. I. (2010). Debating handbook. Retrieved from http://id.scribd.com/doc/41 162209/ Debating-Handbook-Debater.

Yin, R. K. (2009). Case study research: Design and methods (4th ed.). Los Angeles, CA: Sage.

\section{Turkish Abstract}

EFL Sınıfında Tartışma Talimatı: Eleştirel Düşünme ve Konuşma Becerisi Üzerindeki Etkiler

$\mathrm{Bu}$ araştırma, tartışma yönteminin öğrencilerin eleştirel düşünme ve konuşma becerileri kazanımlarını önemli derecede geliştirip arttırmadığını ve eleştirel düşünme ve konuşma becerilerinin her bir yönüne ne kadar tartışmanın katkıda bulunduğunu araştırmayı amaçlamıştır. Araştırmada eşdeğer ön test-son test kontrol grubu tasarımı için yarı deneysel bir çalışma yapılmıştır. Bulgular, (1) eleştirel düşünme ve konuşma becerisinde belirgin bir iyileşme olduğunu, (2) deney ve kontrol grupları arasında da önemli bir fark olduğunu, (3) tartışmaların eleştirel düşünmenin tüm yönlerine yüksek katkıda bulunduğunu göstermiştir.

Anahtar Kelimeler: tartışma, eleştirel düşünme, konuşma becerisi, yönerge, EFL sınıfı

\section{French Abstract}

Instruction de Débat dans Salle de classe EFL: Impacts sur la Pensée Critique et la Compétence à l'oral

La recherche a été visée pour découvrir si vraiment utilisant le débat a significativement amélioré la pensée critique des étudiants et des accomplissements de compétence à l'oral et combien de débat a contribué à chaque aspect de pensée critique et la compétence à l'oral. Une étude quasiexpérimentale de non-équivalent pretest-le design(la conception) de groupe témoin post-de test a été utilisée dans cette recherche. Les découvertes ont montré que (1) il y avait une amélioration significative de la pensée critique et la compétence à l'oral, (2) il y avait aussi une différence moyenne significative entre l'expérimental et des groupes témoins, (3) il y avait la haute contribution du débat vers les aspects entiers de pensée critique.

Mots Clés: debate, critical thinking, speaking skill, instruction, EFL classroom

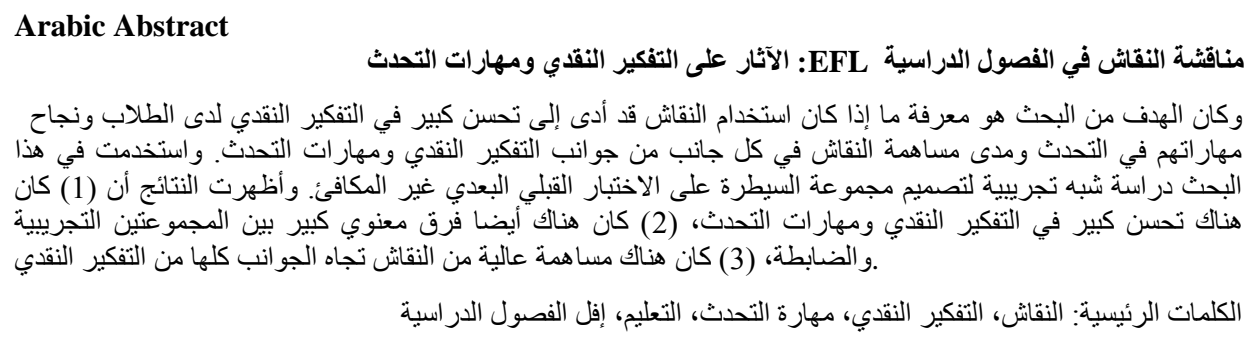




\section{German Abstract \\ Debatte Instruction in EAZ Klassenzimmer: Auswirkungen auf die Kritischen Denken und Sprechen Fähigkeiten}

Die Forschung zielte darauf ab, herauszufinden, ob die Debatte die kritische Denkweise und das Sprechen der Fähigkeiten der Schülerinnen und Schüler deutlich verbessert hat und wie viel Diskussion zu jedem Aspekt des kritischen Denkens und Sprechens geschafft hat. In dieser Forschung wurde eine quasi-experimentelle Studie von nicht-äquivalenten Pretest-PosttestKontrollgruppen-Design verwendet. Die Ergebnisse zeigten, dass (1) eine signifikante Verbesserung der kritischen Denk- und Sprechfertigkeiten bestand, (2) es gab auch einen signifikanten mittleren Unterschied zwischen den experimentellen und Kontrollgruppen, (3) gab es einen hohen Beitrag der Debatte zu den ganzen Aspekten des kritischen Denkens.

Schlüsselwörter: debatte, kritisches denken, sprechen geschick, unterricht, EFL klassenzimmer

\section{Malaysian Abstract \\ Arahan Perbahasan dalam Kelas EFL: Kesan Pemikiran Kritikal dan Kemahiran Berkomunikasi}

Kajian ini bertujuan untuk mengetahui sama ada atau tidak menggunakan perbahasan dengan ketara meningkatkan pemikiran kritis pelajar dan pencapaian kemahiran berkomunikasi dan berapa banyak perbahasan menyumbang kepada setiap aspek pemikiran kritis dan kemahiran komunikasi. Kajian kuasi eksperimen tentang reka bentuk kumpulan kawalan pretest-posttest kumpulan yang tidak bersamaan digunakan dalam kajian ini. Hasil kajian menunjukkan bahawa (1) terdapat peningkatan yang signifikan dalam pemikiran kritikal dan kemahiran berbicara, (2) terdapat perbezaan yang signifikan antara kelompok eksperimen dan kawalan, (3) terdapat sumbangan yang tinggi terhadap perdebatan terhadap seluruh aspek pemikiran kritikal.

Kata Kunci: perbahasan, pemikiran kritikal, kemahiran berkomunikasi, arahan, kelas EFL

\section{Russian Abstract \\ Дискуссионная Инструкция в Классе EFL: Влияние на Критическое Мышление и Умение Говорить}

Цель исследования состоит в том, чтобы исследовать, значительно ли улучшает процесс обсуждения навыки критического мышления и речи, а также то, как много обсуждений способствует каждому аспекту критического мышления и умения говорить. В этом исследовании использовалось квази-экспериментальное исследование неэквивалентного предварительного тестирования - посттест контрольная группа. Результаты показали, что (1) произошло значительное улучшение критического мышления и умения говорить, (2) было также значительное среднее различие между экспериментальной и контрольной группами, (3) был высокий вклад дебатов во все аспекты критического мышления.

Ключевые Слова: дебаты, критическое мышление, умение говорить, обучение, класс EFL 